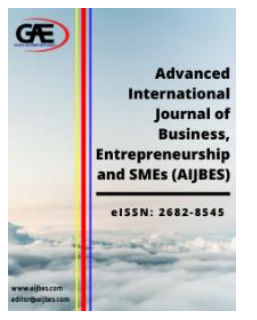

\author{
ADVANCED INTERNATIONAL JOURNAL OF \\ BUSINESS, ENTREPRENEURSHIP AND SMES \\ (AIJBES) \\ www.aijbes.com
}

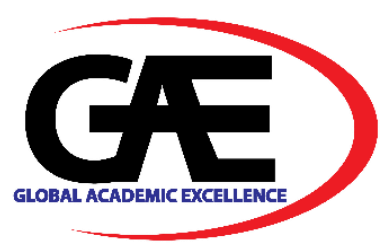

\title{
DETERMINANTS OF CONSUMER PURCHASE DECISION IN MAKEUP ARTIST SERVICES
}

\author{
Nurul Khotimah ${ }^{1 *}$, Nurrani Kusumawati ${ }^{2}$ \\ $1 \quad$ School of Business and Management, InstitutTeknologi Bandung \\ Email: nurul_khotimah@sbm-itb.ac.id \\ 2 School of Business and Management, InstitutTeknologi Bandung \\ Email: nurrani.k@sbm-itb.ac.id \\ Corresponding Author
}

\section{Article Info:}

Article history:

Received date: 26.08 .2021

Revised date: 27.10 .2021

Accepted date: 15.11.2021

Published date: 01.12.2021

\section{To cite this document:}

Khotimah, N., \& Kusumawati, N. (2021). Determinants Of Consumer Purchase Decision In Makeup Artist Services. Advanced International Journal of Business, Entrepreneurship and SMEs, 3 (10), 24-38.

DOI: $10.35631 / A I J B E S .310003$.

This work is licensed under CC BY 4.0 (a)

\begin{abstract}
:
Nowadays, not all women can make themselves up properly and perfectly to attend an important event, so they need Makeup Artist (MUA) services. Supported by technological advances where consumers are starting to leave the traditional way of finding MUA from salons near their homes whose quality is unknown, so MUA services platforms exist. The number of MUAs spread across Indonesia has reached 500,000. The large business opportunity as MUA in Indonesia means that MUAs must be able to maintain their business in the face of competition because consumers have many considerations in choosing and buying services. On the other hand, MUA still has difficulty getting consumers and the MUA services still does not know about the consumer purchase decision. The purpose of this study is to determine consumer purchasing decisions for MUA services, factors that influence the purchasing decision for the MUA services, and marketing communications that are suitable for the consumer purchase decision. The data analyzed with a mix method, qualitatively and quantitatively. Qualitative methods are used in-depth interviews with coding and quantitative methods by distributing questionnaires online using SmartPLS 3.0. The results of qualitative analysis from the informant's explanation divided into eight subjects, there are reasons for using MUA service, need fulfillment, specific time, source of information, consideration when choose MUA services, MUA services comparison, customer satisfaction, and considerations when choose MUA services platform. The research of quantitative analysis reveals that perceived risk, sales promotion and direct marketing have a negative significant relationship on purchase decision, whereas tie strength and involvement have a positive significant relationship on WOM influence. Meanwhile, WOM influence and advertising have a positive significant relationship on purchase decision for MUA services. The findings of this study give recommendations to MUA services to focus on advertising, provide review features, and create attractive portfolios.
\end{abstract}


Keywords:

Purchase Decision, Makeup Artist, Makeup Artist Services, Qualitative, Quantitative, PLS

\section{Introduction}

Women and makeup are two things that cannot be separated. Makeup is one of the most important things in starting activities by dressing up in the mirror for women. The application of makeup to individuals, especially women, is increasingly important. It turns out that not all women can apply their makeup to their faces. Makeup Artist (MUA) services is a provider of makeup services by covering the imperfections and accentuating the advantages that exist in the face of an individual (Khogidar, 2013). The desire of every woman to beautify herself through makeup is very high, but not all women can makeup properly and perfectly. Even though everyday women makeup their faces, not all women can makeup their faces for special events.

Supported by technological advances where customers are starting to leave the traditional way of finding MUA from salons near their homes whose quality is unknown. Currently, consumers choose to look for MUA by looking at their portfolio or examples of makeup that have been done which are usually easy to find through social media, especially Instagram (Casaló, Flavián, \& Ibáñez-Sánchez, 2020). Through Instagram, MUA uploads their portfolios, and people will see and be interested then contact the MUA to order the services for makeup, even many MUAs provide home services with additional transportation costs. Despite the presence of social media, women still have difficulty finding information about the MUA that suits their expectations. They should check one by one about the portfolio of MUA services, they would check the portfolio through recommendations from their family or friends. The thing that usually happens is someone else already books the MUA at the desired time and date, this makes women have to contact MUA again until they have found the MUA. This is very inefficient to do because they have to wait for confirmation from the MUA they want, otherwise, they have to look for MUA again with a repeating pattern.

According to Dennish Tjandra (CEO of Hello Beauty), the number of MUAs spread across Indonesia has reached 500,000 (Widia, 2017). Based on data by BPS-Statistics Indonesia (2020), Indonesia's population is currently dominated by the productive age group between 15 - 64 years. BPS distinguishes the population of productive age into two categories, the first is very productive age $(15-49)$ and the second is the productive age $(50-64)$. The number of women with a very productive age reaches 134.2 million in Indonesia. This shows there is a large market opportunity for MUAs in offering their services and starting a business in the beauty services industry. The large business opportunity as MUA in Indonesia means that MUAs must be able to maintain their business in the face of competition. Consumers have many considerations in choosing and buying services (Suryaningtyas, 2015). Therefore, MUA is required to have various factors that can attract consumers' attention to make purchases or use the services offered by the MUA. However, the thing that still happens often is that it is difficult for women to find MUA services and other beauty services (CEO of Hello Beauty, 2018). For this reason, the MUA service platform exists as a beauty service to assist women in choosing and finding information about MUA services. On the other hand, MUA still has difficulty getting customers. This is especially felt by MUAs who are just starting their careers in this industry. 
This should be a special concern for business actors in the beauty industry. In this highly competitive era, the marketing model has become an extensively acknowledged marketing method (Qiu, 2018). This marketing greatly guides significance for consumer purchasing decisions (Palese\&Usai, 2018; Hasan et al., 2012). Purchasing decisions involve an order of choices made by consumers before making a purchase that begins with a desire to meet needs. Consumers become aware there is a difference between the real conditions and the desired conditions. This causes consumers to find more information to find out the products or services they want. The consumer has to reach a decision regarding the place of purchase, the desired brand, the purchase amount, the time to buy, the amount of money to be spent, and the method of payment. This decision can be influenced by marketers by providing information about their product or service that can inform the consumer assessment process.

When the business already knows how the process of each purchase decision stage is, this will lead to the most suitable marketing communication for the business to use. Marketing communication has evolved into a critical aspect, a business vision, and a critical factor in the success of marketing activities. Its significance has grown significantly in recent decades, as marketing and communication have become inseparable activities, with all businesses utilizing various types of marketing communication to convey their products or services to their target audience (Shimp, 2003). Through communication, marketing activities will be able to achieve the desired thing, one of the things is the buying process. The consumers can learn about what products or services are offered, who produces or offers their services, who is the target market, what are their advantages, where can they be obtained, and how to get them. Marketing communication has a very important role for businesses to communicate products or services that are marketed to a wider target market, even helping in brand awareness, increase sales and expand markets.

\section{Literature Review}

\section{Purchase Decision Process}

The purchase decision is defined as the stage in a purchase decision process when customers determine whether to purchase the product or services under consideration (Kotler \& Armstrong, 2014). There are five stages in the customer purchase decision process. The first stage is needed recognition, the second is information search, the third stage is evaluation, the fourth is purchase decision and the fifth stage is post-purchase behavior (Kotler \& Keller, 2012).

a. Need Recognition: The beginning of the purchasing process, at these stage consumers already have an awareness that they need something (Kotler \& Keller, 2012).

b. Information Search: The more consumers know about a product or service, it makes them no need to spend a lot of time looking for information. Conversely, the more excited they are about a product or service, the more time they can devote to researching it (Lamb et al., 2011).

c. Evaluation: At this point, customers would begin to wonder, "Do I need this product or service?" "Is there an alternative to this?" and consider the advantages it would have. This is done to get the best deal before buying the product or service (Kotler \& Keller, 2012).

d. Purchase Decision: In this stage, consumers make the decisions about which products or services to purchase or whether not to buy anything at all. Factors that influence the 
Volume 3 Issue 10 (December 2021) PP. 24-38 DOI 10.35631/AIJBES.310003

purchase stage are whether to purchase when to purchase, what to purchase, where to purchase, and how to pay (Lamb et al., 2011).

e. Post-Purchase Behavior: The last stage is post-purchase (satisfaction or dissatisfaction). The customer will use and evaluate the product at this stage. "Does this product suit the customer's needs?" "Have they met their expectations?" (Kotler \& Keller, 2012).

\section{WOM Influence}

WOM communication is described as an influential form of information that affects purchasing decisions (Bansal \& Voyer, 2000). According to WOMMA (Word Of Mouth Marketing Association), as mentioned by (Barber, Peggy, Wallace, 2010), WOM Influence is an activity in which consumers share information about a product or service with other consumers. WOM is more influential in the context of services since services are intangible, difficult to judge before to purchase, are not covered by warranty, and are not standardized, making the decision more riskier than products (Jill Sweeney, 2014). WOM is critical for service providers whose offers are predominantly intangible and rely on experience (Houshang Taghizadeh, 2013). Therefore, consumers mainly rely on reviews from others who have used the service.

\section{Tie Strength}

Tie Strength can be described as the level of intensity of social relations between consumers. Various ties of relationships in social networks owned by consumers generally include strong primary ties such as family or close friends to weak secondary ties such as people that infrequently communicate to strangers (Steffes et al., 2008). Tie Strength is considered strong if the source comes from someone whom consumers know when making purchasing decisions (Bansal \& Voyer, 2000).

\section{Involvement}

Involvement can be described as motivation in processing information. Service information gets the attention of consumers to activate motivational states that drive behavior (Putra et al., 2020). The level of individual involvement affects the level of information needed because the higher the level of involvement, the higher the level of information needs and vice versa (Doh \& Hwang, 2009). However, WOM is relevant to purchase decisions. Its inclusion in service purchase decisions will have a significant impact on WOM. The role of involvement is significant because it relates to the internal, specifically the relationship between the individual decision-maker and the perceived relevance of the purchase decision (Qonitah \& Nuraeni, 2020).

\section{Perceived Risk}

Perceived Risk is a term that refers to a consumer's perception of the uncertainty in the purchase of a product or service (Hackett, Schwarzenbach, \& Jürgens, 2016). Consumers cannot be knowledgeable of the possibility of risk factors occurring as a consequence of these purchases because basically every consumer action has consequences, whether pleasant or unpleasant or beneficial or unfavorable (Vo \& Nguyen, 2015). As a result, if consumers perceive a product or service to be risky, they would lessen or cancel the purchase decision (Kardes, Herr, \& Schwarz, 2019). According to one study, consumers consider service decisions riskier than product decisions, especially in terms of social risk, physical risk, and psychological risk. Perceived risk is typically measured using a multidimensional scale: financial risk, physical risk, performance risk, time risk, and social risk (Cunningham, Gerlach, Harper, \& Young, 2005). 


\section{Marketing Communication}

Marketing communications reflect the aggregation of all components in a company's marketing mix, promoting interactions through establishing shared meanings with brand stakeholders (Kotler \& Philip, 2003). The marketing communications mix consists of six critical components, while some authors mention additional components. These include sales promotion, advertising, public relations, direct marketing, personal selling, and events and experiences (Kotler \& Keller, 2009). Sales promotion is a specialized approach that companies utilize to encourage customers to purchase a product or service within a specified time (Solomon et al., 2008). Advertising is the delivery of announcements and promotional messages through the purchase of time or space in various media (Boove \& Thill, 2011). Direct marketing is used to establish a long-term relationship with customers in order to obtain something in return, such as profits and sales (Kolter\& Armstrong, 2008). Previous studies have explored this topic like the research about the influence of integrated marketing communication mix on consumer purchasing decision (Sualang, 2015). The results from those studies stated that sales promotion, advertising, and direct marketing have a significant influence on consumer purchasing decisions.

In this study, researchers wanted to analyze determinants of consumer purchase decisions in MUA services. The result of this research can be used to determine the purchase decision and analyze the factors that influence consumers in finding MUA services. Furthermore, to determine the factors that affect the purchase decision of the MUA services platform, below are the following set of hypotheses in this study:

H1: WOM Influence has a significant positive relationship toward Purchase Decision.

H2: Tie Strength has a significant positive relationship toward WOM Influence

H3: Involvement has a significant positive relationship toward WOM Influence.

H4: Perceived Risk has a significant positive relationship toward Purchase Decision.

H6: Sales Promotion has a significant positive relationship toward Purchase Decision.

H7: Advertising has a significant positive relationship toward Purchase Decision.

\section{Methodology}

\section{Qualitative Approaches}

In this study, the researchers used qualitative analysis to gain deeper insights into the problem that could be used to validate the data findings from the quantitative analysis and to find the customer purchase decision of consuming the MUA services. Malhotra (2010) defines qualitative research as an exploratory and unstructured research method focused on small samples that aim to elicit information and perceptions on problem settings. In this study, a semi-structured interview will be used as the qualitative method. Semi-structured interviews consist of a sequence of open-ended questions based on the topics the researcher wants to discuss.

\section{Data Analysis}

\section{Coding}

Manual coding is the first step toward conducting a thorough analysis and interpretation (Saldaňa, 2012). Coding was used to transform raw qualitative data into a summary of the issues discovered, which was then organized into categories. Manual coding can be accomplished in a variety of methods. 


\section{Triangulation}

After manual coding, the data will be triangulated. According to Maxwell (2013), triangulation is used to prevent researchers from misinterpreting interview results.

\section{Quantitative Approach}

This study uses quantitative analysis to generate numerical data that can be translated into statistical data to solve the problem. Quantitative data is a type of research methodology that involves the use of mathematical or scientific data to comprehend a situation. In quantitative research, statistical analysis will be used to interpret the data (Malhotra, 2010).

\section{Survey Method}

Malhotra (2010) described survey methods as questioning respondents to gather information. This research distributes questionnaires through social media and online messenger using the google form link. Researchers distributed questionnaires to women who have ever used MUA services in Bandung and its surroundings. The item questions will be using Bahasa Indonesia because the researcher spread the questionnaire to respondents that use Bahasa Indonesia as their mother tongue. The data obtained from this questionnaire enables the researcher to determine the relationship between the independent variable and the dependent variable as outlined in the hypothesis.

\section{Data Analysis}

\section{Partial Least Square - Structural Equation Model (PLS-SEM)}

Partial Least Squares - Structural Equation Modeling (PLS-SEM) is the second-generation method of multivariate data analysis is used to test the theoretical additive and linear causal models in marketing research (Chin, 1996; Haenlein\& Kaplan, 2004; Statsoft, 2013). This is appropriate for research with endogenous variables, non-normal multivariate data, a limited number of available responses, and reflective objects (Achjari, 2004). This study has a complex model and a limited number of samples, so the data analysis uses SmartPLS software.

\section{Data Collection}

\section{Population and Sample}

These research target populations are women aged 19-36 years who live in Bandung and surroundings, have ever used the services of MUA. The sample size refers to the number of items that will be included in the study. According to Malhotra (2010), the minimum sample size for marketing studies should be 200 respondents. This research will use non-probability sampling

\section{Discussion and Analysis}

\section{Qualitative Approach}

\section{Result}

An in-depth interview was conducted with 8 participants with the qualification of women aged 16 to 39 that lived in Bandung and have used MUA services. This interview was conducted online via Google Meet due to the pandemic. The qualitative analysis is collected from the informant's explanation which is then divided into eight subjects: (1) reason for using MUA service, (2) need fulfillment, (3) specific time, (4) source of information, (5) consideration 
when choose MUA services, (6) MUA services comparison, (7) customer satisfaction, and (8) considerations when choose MUA services platform.

\section{Reason for Using MUA Service}

The reason for women to use MUA services is due to the skill that is not possessed to be able to apply makeup on their own to attend a special occasion. These results are consistent with the findings from (Dumas, et al., 2017; McCain et al., 2016), which states not all women have the skills to do their makeup, so they need the services of MUA to beautify their face. Many of the reasons for women finding MUA services include the desire to look beautiful for special days and special events (Aytuğ, 2015).

\section{Need Fulfillment}

According to the findings of the interviews, women use makeup to look more beautiful and different than usual at special events they want to attend. This is in line with research conducted by Elianti (2017) where the use of makeup is of course to support the appearance and beauty of women because a beautiful appearance is something that every woman always wants to fulfill.

\section{Specific Time}

Based on the interview results, they use MUA's services to attend special events such as graduations and family events that require makeup such as weddings or engagement days. Some also answered for photoshoots and yearbooks. This is in line with research conducted by Elianti (2017) where women wear makeup to be used when attending an event, shooting, photoshoot, wedding, and other events.

\section{Sources of Information}

Based on the interview result, most interviewees get Word Of Mouth (WOM) information about MUA services from friends or family they know and trust. In line with research (Bansal et al, 2000) which states that WOM s proven to be more effective in conveying information.

\section{Consideration When Choose MUA Services}

Most of those interviewed consider the portfolio and also the price to choose MUA services. Of all that, the most important thing for them to consider is the MUA portfolio. This is in line with research (Casaló, Flavián, \& Ibáñez-Sánchez, 2020) which states that currently, consumers choose to find MUA services by looking at their portfolio or the results of makeup that has been done which is usually easy to find.

\section{MUA Services Comparison}

Based on the interviews, most of those interviewed said that they compared MUA's services to one another, although some answered no to this. In research (Wilkie, 1994) states that consumers compare the performance expectations of service before buying with the perception of the actual performance of the service. Consumers will feel satisfaction when the expectations before the purchase match or exceed the consumer's perception of the actual performance of a service.

\section{Customer Satisfaction}

Based on the results of interviews, most of those interviewed stated satisfied with the MUA services they had used and they gave recommendations to others to use the services of MUA which they felt the results were satisfactory. This is in line with the research of Irawan (2002) 
Volume 3 Issue 10 (December 2021) PP. 24-38 DOI 10.35631/AIJBES.310003

which stated that if consumers are satisfied, they will tend to continue to buy and use the service and tell others about a pleasant experience with the service.

\section{Considerations when Choose MUA Services Platform}

Based on the results of the interview, the interviewee considered the features contained in the MUA services platform to provide convenience when using it. These features include portfolio, price, location, and ease of booking the MUA service including payment. This is by, previous research (Prasetyo et al, 2015) which states that the higher the level of ease of use of the platform, the higher consumer buying interest. It can be concluded that a platform can be said to be good when consumers feel that the platform provides convenience for consumers. If the platform provides clear instructions for the flow of transactions, from ordering, paying, to receiving the service, as well as the availability of various features that can make it easier for consumers on the platform, then consumers will use the platform.

\section{Quantitative Approach}

Table 1: The Value of The Reliability

\begin{tabular}{|c|c|c|c|}
\hline Variables & Indicators & $\begin{array}{c}\text { Outer } \\
\text { Loading }\end{array}$ & Reliability \\
\hline \multirow[t]{3}{*}{ Advertising } & AD1 & 0.938 & Reliable \\
\hline & AD2 & 0.936 & Reliable \\
\hline & AD3 & 0.955 & Reliable \\
\hline \multirow{4}{*}{$\begin{array}{l}\text { Purchase } \\
\text { Decision }\end{array}$} & DCS1 & 0.938 & Reliable \\
\hline & DCS2 & 0.931 & Reliable \\
\hline & DCS3 & 0.863 & Reliable \\
\hline & DCS4 & 0.814 & Reliable \\
\hline \multirow[t]{3}{*}{ Direct Marketing } & DM1 & 0.816 & Reliable \\
\hline & DM2 & 0.806 & Reliable \\
\hline & DM3 & 0.840 & Reliable \\
\hline \multirow[t]{3}{*}{ Involvement } & INVM1 & 0.969 & Reliable \\
\hline & INVM2 & 0.960 & Reliable \\
\hline & INVM3 & 0.914 & Reliable \\
\hline Perceived Risk & FNCL2 & 0.883 & Reliable \\
\hline
\end{tabular}


Volume 3 Issue 10 (December 2021) PP. 24-38 DOI 10.35631/AIJBES.310003

\begin{tabular}{|c|c|c|c|}
\hline & OPRT2 & 0.770 & Reliable \\
\hline & PRFM2 & 0.894 & Reliable \\
\hline & PSC2 & 0.952 & Reliable \\
\hline & PSC4 & 0.915 & Reliable \\
\hline & PSHC2 & 0.761 & Reliable \\
\hline & SOC1 & 0.709 & Reliable \\
\hline & SOC3 & 0.782 & Reliable \\
\hline & TM1 & 0.764 & Reliable \\
\hline & TM3 & 0.800 & Reliable \\
\hline Sales Promotion & SP1 & 0.976 & Reliable \\
\hline & SP2 & 0.980 & Reliable \\
\hline & SP3 & 0.953 & Reliable \\
\hline Tie Strength & TS1 & 0.915 & Reliable \\
\hline & TS2 & 0.957 & Reliable \\
\hline & TS3 & 0.952 & Reliable \\
\hline WOM Influence & WOM1 & 0.908 & Reliable \\
\hline & WOM2 & 0.949 & Reliable \\
\hline & WOM3 & 0.937 & Reliable \\
\hline
\end{tabular}

According to the results in Table 1, all variables reach the minimal preferred score, indicating that all variables are reliable and acceptable for further processing. 
Volume 3 Issue 10 (December 2021) PP. 24-38

Table 2: Internal Consistency Reliability Result

\begin{tabular}{|l|c|l|}
\hline \multicolumn{1}{|c|}{ Variables } & Composite Reliability & Reliability \\
\hline Advertising & 0.960 & Reliable \\
\hline Direct Marketing & 0.861 & Reliable \\
\hline Involvement & 0.964 & Reliable \\
\hline Perceived Risk & 0.955 & Reliable \\
\hline Purchase Decision & 0.937 & Reliable \\
\hline Sales Promotion & 0.979 & Reliable \\
\hline Tie Strength & 0.959 & Reliable \\
\hline WOM Influence & 0.952 & Reliable \\
\hline
\end{tabular}

Table 2 shows that all of the variables' composite reliability scores are greater than 0.7 , indicating that internal consistency reliability is high. As a result, it can conclude that all of the variables are reliable.

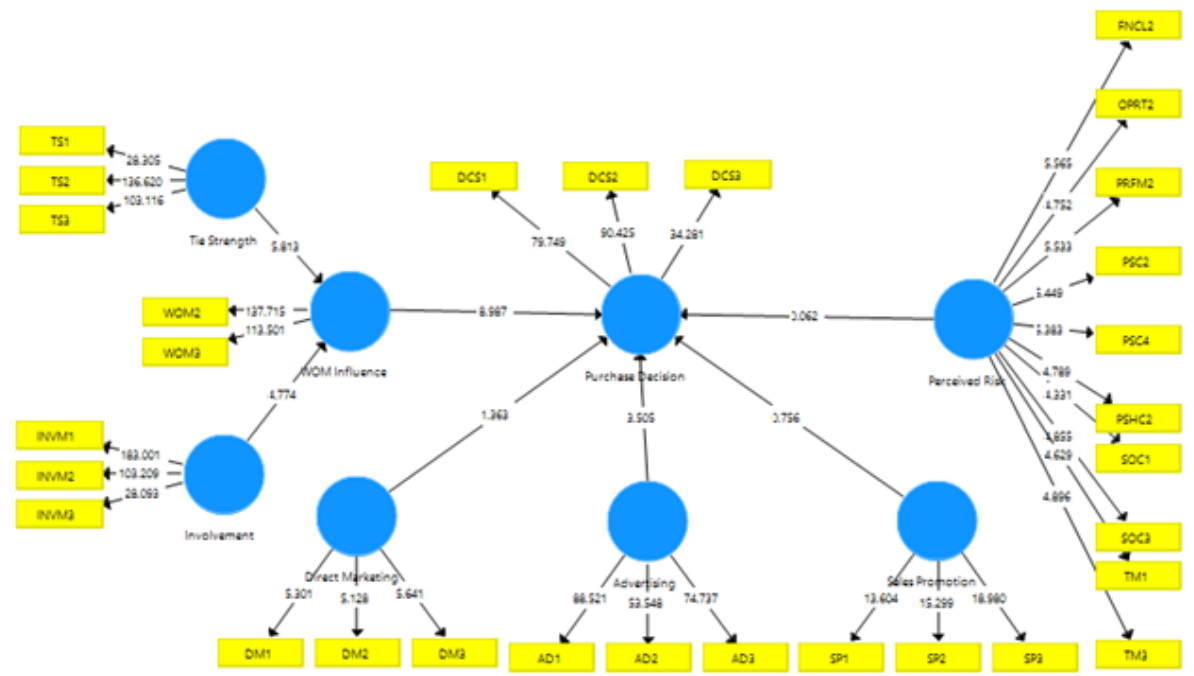

Figure 1: Bootstrapping Result

Partial Least Squares is utilized to determine the causal effect based on the conceptual framework used in this research. This current model consists of 8 constructs and 30 indicators. Tie Strength consists of three indicators. Involvement consists of three indicators. WOM Influence consists of two indicators. Purchase Decision consists of three indicators. Perceived Risk consists of ten indicators. Direct Marketing consists of three indicators. Advertising consists of three indicators and Sales Promotion consists of three indicators. 
Volume 3 Issue 10 (December 2021) PP. 24-38 DOI 10.35631/AIJBES.310003

There are some attributes to consider while evaluating the model's quality, including Path coefficients, coefficient of determination (R2), and cross-validated redundancy (Q2). The significance of the model's relationship is indicated by t-values, which must be greater than or equal to 1.96 as criteria.

Table 3: Structural Path Significance

\begin{tabular}{|c|c|c|c|c|c|}
\hline Structural Path & $\begin{array}{c}\text { Path } \\
\text { Coefficient }\end{array}$ & $\begin{array}{l}\text { T Statistics } \\
(|\mathrm{O} / \mathrm{STDEV}|)\end{array}$ & $\begin{array}{c}\mathbf{P} \\
\text { Values }\end{array}$ & $\mathbf{R}^{2}$ & $\mathbf{Q}^{2}$ \\
\hline $\begin{array}{l}\text { Advertising } \rightarrow \text { Purchase } \\
\text { Decision }\end{array}$ & 0.283 & 3.322 & 0.001 & \multirow[t]{5}{*}{0.782} & \multirow[t]{5}{*}{0.653} \\
\hline $\begin{array}{l}\text { Direct Marketing } \rightarrow \text { Purchase } \\
\text { Decision }\end{array}$ & 0.055 & 1.348 & 0.178 & & \\
\hline $\begin{array}{l}\text { Perceived Risk } \rightarrow \text { Purchase } \\
\text { Decision }\end{array}$ & 0.003 & 0.060 & 0.952 & & \\
\hline $\begin{array}{l}\text { Sales Promotion } \rightarrow \text { Purchase } \\
\text { Decision }\end{array}$ & 0.022 & 0.706 & 0.480 & & \\
\hline $\begin{array}{l}\text { WOM Influence } \rightarrow \text { Purchase } \\
\text { Decision }\end{array}$ & 0.658 & 8.856 & 0.000 & & \\
\hline $\begin{array}{l}\text { Involvement } \rightarrow \text { WOM } \\
\text { Influence }\end{array}$ & 0.436 & 4.291 & 0.000 & \multirow[t]{2}{*}{0.863} & \multirow[t]{2}{*}{0.802} \\
\hline $\begin{array}{l}\text { Tie Strength } \rightarrow \text { WOM } \\
\text { Influence }\end{array}$ & 0.525 & 5.234 & 0.000 & & \\
\hline
\end{tabular}

The coefficient of determination $\left(\mathrm{R}^{2}\right)$ is used to assess the predictive accuracy of a model (Wong, 2013). $\mathrm{R}^{2}$ is a coefficient that ranges between 0 and 1 according to the prediction accuracy of the dependent variable (Hair et al., 2014). The $\mathrm{R}^{2}$ of the purchase decision is 0.782 , which means that five latent variables (Advertising, Direct Marketing, Perceived Risk, Sales Promotion, and WOM Influence) explain $78.2 \%$ of the variance in a purchase decision. Then, $\mathrm{R}^{2}$ of WOM Influence is 0.862, meaning that two latent variables (Involvement and Tie Strength) explain the $86.2 \%$ of the variance in WOM Influence.

The Stone-Geisser test $\left(\mathrm{Q}^{2}\right)$ is used to determine the predictive relevance. The $\mathrm{Q}^{2}$ result can be acquired by running the blindfolding procedure in SmartPLS. In this research, the purchase decision has a $\mathrm{Q}^{2}$ value of 0.653 and WOM Influence has 0.802 . $\mathrm{Q}^{2}$ value greater than 0 indicates that a model has predictive relevance. Because the $\mathrm{Q}^{2}$ values for all variables are greater than 0 , it can conclude that the model has predictive relevance. 
Volume 3 Issue 10 (December 2021) PP. 24-38 DOI 10.35631/AIJBES.310003

Table 4: Hypothesis Testing

\begin{tabular}{|l|l|c|c|c|l|}
\hline Hypothesis & \multicolumn{1}{|c|}{ Structural Path } & $\begin{array}{c}\text { Path } \\
\text { Coefficient }\end{array}$ & $\begin{array}{c}\text { T } \\
\text { Values }\end{array}$ & $\begin{array}{c}\text { P } \\
\text { Values }\end{array}$ & Result \\
\hline H1 & $\begin{array}{l}\text { WOM } \\
\text { Influence } \rightarrow \text { Purchase } \\
\text { Decision }\end{array}$ & 0.658 & 8.856 & 0.000 & Accepted \\
\hline H2 & $\begin{array}{l}\text { Tie Strength } \rightarrow \text { WOM } \\
\text { Influence }\end{array}$ & 0.525 & 5.234 & 0.000 & Accepted \\
\hline H3 & $\begin{array}{l}\text { Involvement } \rightarrow \text { WOM } \\
\text { Influence }\end{array}$ & 0.436 & 4.291 & 0.000 & Accepted \\
\hline H4 & $\begin{array}{l}\text { Perceived Risk } \rightarrow \text { Purchase } \\
\text { Decision }\end{array}$ & 0.003 & 0.060 & 0.952 & Rejected \\
\hline H5 & $\begin{array}{l}\text { Sales Promotion } \rightarrow \\
\text { Purchase Decision }\end{array}$ & 0.022 & 0.706 & 0.480 & Rejected \\
\hline H6 & $\begin{array}{l}\text { Advertising } \rightarrow \text { Purchase } \\
\text { Decision }\end{array}$ & 0.283 & 3.322 & 0.001 & Accepted \\
\hline H7 & $\begin{array}{l}\text { Direct Marketing } \rightarrow \\
\text { Purchase Decision }\end{array}$ & 0.055 & 1.348 & 0.178 & Rejected \\
\hline
\end{tabular}

Based on table 4, it can be seen that the research reveals that perceived risk, sales promotion and direct marketing have a negative significant relationship on purchase decision, whereas tie strength and involvement have a positive significant relationship on WOM influence. Meanwhile, WOM influence and advertising have a positive significant relationship on purchase decision for MUA services.

Table 5: f Square Result

\begin{tabular}{|l|c|c|}
\hline & Purchase Decision & WOM Influence \\
\hline Advertising & 0.198 & \\
\hline Direct Marketing & 0.012 & \\
\hline Involvement & & 0.347 \\
\hline Perceived Risk & 0.000 & \\
\hline Purchase Decision & & \\
\hline Sales Promotion & 0.002 & \\
\hline Tie Strength & & 0.501 \\
\hline WOM Influence & 1.061 & \\
\hline
\end{tabular}


Based on Table 5, it can be concluded Perceived Risk - Purchase Decision and Sales Promotion - Purchase Decision have a weak effect size. Then, Direct Marketing - Purchase Decision has a moderate effect size. Last, Advertising - Purchase Decision, WOM Influence - Purchase Decision, Involvement - WOM Influence, and Tie Strength - WOM Influence have strong effect sizes.

\section{Conclusions}

This research studied on consumer purchase decision for MUA services. Based on the analysis it can be concluded, the purchase decision stage to consume the MUA services at the need recognition stage, women have reasons for using MUA services because they need skills from MUA because they do not have the skills to makeup for special events. In addition, there is a need for fulfillment, such as the desire to seem beautiful and different at special events. Finally, they use MUA services when attending special events such as weddings, engagements, graduations, etc. At the searching for information stage, consumers looking for information through WOM whose information comes from their friends or family. At the evaluation stage, the consideration when choosing MUA services is the portfolio of the MUA and the price. In addition, most of the consumers do MUA services comparison with one another to get the best MUA. At the purchase decision stage, consumers decide to use MUA services after going through the previous three stages. At the Post-Purchase Behavior stage, if consumers are satisfied with MUA services, they will provide recommendations to others to use the MUA services. From the result of the PLS, the WOM Influence has a significant positive relationship toward Purchase Decision, these results indicate that women in finding MUA services consider the influence of WOM before deciding to make a purchase decision on MUA services. Tie Strength has a significant positive relationship toward WOM Influence, these results indicate that women who find MUA services from WOM Influence are influenced by Tie Strength compared to Weak Ties when getting recommendations for MUA services by WOM. Involvement has a significant positive relationship toward WOM Influence, these results indicate that high involvement means that consumers will show a high level of intention to seek information on MUA services, evaluate MUA services, and purchase decisions. Meanwhile, Perceived Risk, Sales Promotion, and Direct Marketing have a negative significant relationship toward Purchase Decision. The result also show Advertising has a significant positive relationship toward Purchase Decision, these results indicate that women looking for MUA services consider advertising about MUA services before deciding to make a purchase decision on MUA services. Consumers feel that through informative and persuasive messages, advertisements provide a promise about the existence of MUA services that can meet the needs and quality of the MUA services they are looking for.

After evaluating the factors that influence the purchasing decision for the MUA services and according to the interview and questionnaire result, the researcher made some recommendations for the MUA services to provide reviews features and create advertisements that make consumers to use MUA services. For future research, it is recommended to find other factors that can significantly influence purchase decisions on the MUA services. Researchers have provided recommendations for marketing communications that are suitable for the consumer purchase decision. 


\section{References}

Barber, Peggy, Wallace, L. (2010). Building a Buzz \& Word of Mouth Marketing. American Library Association.

Boove, C. L., and Thill, J.V., (2011). Business in Action, 5th edition. ISBN: 978-0-13-2546881. Pearson, United States.

Casaló, Luis V., Carlos Flavián, \& Sergio Ibáñez-Sánchez. (2020). 'Be Creative, My Friend! Engaging Users on Instagram by ProJuska, J. M. (n.d.). Integrated Marketing Communication Advertising and Promotion in a Digital World Moting Positive Emotions.' Journal of Business Research, no. February: 1-10. https://doi.org/10.1016/j.jbusres.2020.02.014.

Chin, W. W., Marcolin, B. L., \&Newsted, P. R. (1996). 'A Partial Least Squares Latent Variable Modelling Approach for Measuring Interaction Effects: Results from a Monte Carlo Simulation Study and Voice Mail Emotion/Adoption Study'. Paper presented at the 17th International Conference on Information Systems, Cleveland, $\mathrm{OH}$.

Cunningham, L.F., Gerlach, J.H., Harper, M.D. \& Young, C.E. (2005), 'Perceived Risk and The Consumer Buying Process: Internet Airline Reservations', International Journal of Service Industry Management, Vol. 16 No. 4, pp. 357372.https://doi.org/10.1108/09564230510614004.

Doh, S.J. \& Hwang, J.S. (2009) 'How Consumers Evaluate EWOM (Electronic Word-OfMouth) Messages', Cyberpsychology\& Behavior, 12(2), 193-197.

Harvir S, Bansal. \& Peter A, Voyer. (2000) 'Word-of-Mouth Processes within a Service Purchase Decision', Journal of Service Research, 3(2), pp. 166-177. doi: 10.1177/109467050032005.

HoushangTaghizadeh, M. J. (2013). 'The Effect of Customer Satisfaction on Word of Mouth Communication', Research Journal of Applied Sciences, Engineering and Technology, 2569-2575.

Jill Sweeney, G. S. (2014). 'Factors Enhancing Word-of-Mouth Influence: Positive and Negative Service- Related Messages'. European Journal of Marketing, 336-359.

Kardes, F. R., Herr, P. M., \& Schwarz, N. (2019). Handbook of Research Methods in Consumer Psychology. New York: Routledge.

Kotler, P. (2003) Marketing Management. 11th Edition. New Jersey: Prentice Hall.

Kotler, P. \& Armstrong, G. (2008) Principles of Marketing 12th edition. Toronto: Pearson Prentice Hall.

Kotler, P. \& Armstrong, G. (2012) The Buyer Decision Process. In: Principles of Marketing 14th edition. New Jersey: Prentice Hall - Pearson.

Kotler, P. \& Keller K. (2014) Marketing Management 15th edition Saddle River. Prentice Hall. Malhotra, N. K. (2010) Marketing Research-An Applied Orientation 6th edition. NJ, Upper Saddle River: Pearson/Prentice Hall.

Maxwell, J. A. (2013). Qualitative Research Design. An interactive approach. SAG

Putra, I. K. R., \&Darma, G. S. (2020) 'Process of Decisions Making Purchase Online on Instagram Social Media', International Journal of Business, Economics \& Management, 3(1), 165-171. https://doi.org/10.31295/ijbem.v3n1.167

Qiu, Y. (2018) 'Impact of E-commerce Evaluation Authenticity on Consumer Purchase Decision Based on Electroencephalogram Test Technology', NeuroQuantology, 16(5), pp. 481-487. doi: 10.14704/nq.2018.16.5.1352.

Qonitah, U. \&Nuraeni, S. (2020) 'Analysis of Tie Strength and Purchase Decision Involvement towards Word-of-Mouth Influence in Service Business' in International Conference on Economics, Business Economic Education 2019, KnE Social Sciences, pp. 1.064-1079. doi: 10.18502/kss.v4i6.6663. 
Saldaňa, J. (2012). The Coding Manual for Qualitative Researchers (2nd ed.). Thousand Oaks, CA: Sage.

Shimp, T. (2003). Advertising, Promotion: Supplemental Aspects of Integrated Marketing Communications, 6th ed., South-Western, Mason, Chapter 1.

Solomon, M.R., Marshall, G. W. \& Stuart, E. W. (2008). Marketing: Real People, Real Choices, Prentice Hall, New Jersey, pp 422-423.

Sualang, F.D. (2015). 'The Influence Analysis of Integrated Marketing Communication Mix On Consumer Purchasing Decision - Study Case of PT Multi Citra Abadi'. Jurnal Berkala Ilmiah Efisiensi.

Vo, T. T. N., \& Nguyen, C. T. K. (2015). 'Factors Influencing Customer Perceived Quality and Purchase Intention toward Private Labels in the Vietnam Market : The Moderating Effects of Store Image'. International Journal of Marketing Studies, 7(4), 51-63.

Wong, K. K.-K. (2013). Partial Least Squares Structural Equation Modeling (PLS-SEM) Techniques. Marketing Bulletin, 2013, 24, Technical Note 1. 